\title{
TRADE LIBERALIZATION IN ASEAN
}

An empirical study of

the Preferential Trading Arrangements

by

Gerald Tan

Research Notes and Discussions Paper No. 32 INSTITUTE OF SOUTHEAST ASIAN STUDIES

1982 
Publ ished by the

Institute of Southeast Asian Studies, Singapore

All rights reserved. No part of this publication may be reproduced, stored in a retrieval system, or transmitted in any form or by any means, electronic, mechanical, photocopying, recording or otherwise, without the prior permission of the Institute of Southeast Asian Studies.

(C) 1982 Institute of Southeast Asian Studies

ISSN $0129-8828$

ISBN 9971-902-46-X 